\title{
Changes in health indicators related to health promotion and microcredit programs in the Dominican Republic ${ }^{1}$
}

\author{
Anita L. Dohn, ${ }^{2}$ Andrea Chávez, ${ }^{3}$ Michael N. Dohn, ${ }^{2}$ Luis Saturria, ${ }^{3}$ and Carlos Pimentel ${ }^{3}$
}

Suggested citation

Dohn AL, Chávez A, Dohn MN, Saturria L, Pimentel C. Changes in health indicators related to health promotion and microcredit programs in the Dominican Republic. Rev Panam Salud Publica. 2004; 15(3):185-93

ABSTRACT Objective. To assess the impact of health promotion programs and microcredit programs on three communities in the Dominican Republic. One community had only the health promotion program, one community had only the microcredit program, and one community had both a health promotion program and a microcredit program. This pilot project examined the hypothesis that the largest changes in 11 health indicators that were studied would be in the community with both a health promotion program and a microcredit program, that there would be intermediate changes in the community with only a health promotion program, and that the smallest changes would be in the community with only a microcredit program.

Methods. The health promotion programs used community volunteers to address two major concerns: (1) the prevalent causes of mortality among children under 5 years of age and (2) women's health (specifically breast and cervical cancer screening). The microcredit program made small loans to individuals to start or expand small businesses. Outcome measures were based on comparisons for 11 health indicators from baseline community surveys (27 households surveyed in each of the three communities, done in December 2000 and January 2001) and from follow-up surveys (also 27 households surveyed in each of the three communities, in June and July 2002, after the health promotion program had been operating for about 13 months). Households were randomly chosen during both the baseline and follow-up surveys, without regard to their involvement in the microcredit or health promotion programs.

Results. The health indicators improved in all three communities. However, the degree of change was different among the communities $(\mathrm{P}<0.001)$. The community with parallel microcredit and health promotion programs had the largest changes for 10 of the 11 health indicators. Conclusions. Multisector development is known to be important on a macroeconomic scale. The results of this pilot project support the view that multisector development is also important on a microeconomic level, given that the parallel microcredit and health promotion programs resulted in greater change in the measured health indicators than either program alone. As far as we authors know, this is the first published study to quantify changes in health indicators related to parallel health promotion and microcredit programs as compared to control communities with only a health promotion program or a microcredit program.

Key words Health promotion; patient education; knowledge, attitudes, practice; health behavior; socioeconomic factors; Dominican Republic.

1 Some portions of this article appeared first on the Web site of the South American Missionary SocietyUSA (http://www.sams-usa.org).

2 La Iglesia Episcopal Dominicana, La Clínica Esperanza y Caridad, San Pedro de Macorís, San Pedro de Macorís, República Dominicana; and The South American Missionary Society, Ambridge, Pennsylvania, United States of America. Send correspondence to: Michael Dohn, c/o SAMS, PO Box 399,
Ambridge, Pennsylvania 15003, United States of America; e-mail: DohnFamily@episcopalian.org

3 Esperanza Internacional, San Pedro de Macorís, San Pedro de Macorís, República Dominicana. 
Relationships between economic development and health are well recognized (1). However, the intertwining between microeconomic development and health as well as the implications for the organization and operation of microcredit and health promotion programs are unclear. Different approaches to combining health and microeconomic development have come about. A recent review of nine microeconomic development programs interested in improving health found several approaches: two organizations were using a minimalist approach, relying on the microeconomic program to improve health; four organizations were using an integrated model, with the microeconomic development organization taking responsibility for both the microeconomic development and health components; and three were working in parallel or partnership arrangements, with one organization having responsibility for the microeconomic development and another organization having responsibility for the health programs (1).

Various concerns have been raised about integrating microcredit and health programs under one organization. One worry is the loss of efficiency and focus that can occur when a microcredit or a health organization adds other components from a different discipline. Microeconomic and health development organizations are most likely to perform best within their specific areas of expertise, and not when they try to cross over to another discipline. Microcredit and health organizations might best "operate at arm's length from each other," with separate but parallel development programs (2).

This article reports on a pilot project in the Dominican Republic using the parallel model, in which the microcredit and health promotion programs were each managed independently by two different organizations. The project involved research in three communities: two urban neighborhoods adjacent to each other in the Barrio Las Filipinas section of the city of San Pedro de Macorís (which is located in the province of the same name), and a semirural community located about 6 $\mathrm{km}$ north of the city. The community health promotion program operated in both of those adjacent urban neighborhoods of the Barrio Las Filipinas. One of the urban neighborhoods had a microcredit program, and the other did not. The semirural community had a microcredit program but not a health promotion program, thus serving as a control for the health promotion component.

The health promotion program in the two urban communities focused on two primary areas: (1) the prevention, recognition, and basic in-home care related to the prevalent causes of mortality among children under 5 years of age (diarrhea and dehydration, acute respiratory illnesses, and vaccine-preventable diseases) and (2) women's health (specifically breast cancer screening and cervical cancer prevention and screening) $(3,4)$.

During the time that the health promotion program was active, from May 2001 to June 2002, the microcredit program made 276 loans, with a total value of US\$ 31555 (average loan of around US\$ 115) in the one Las Filipinas neighborhood. During this same period, in the semirural community the microcredit program made 97 loans, totaling US\$ 27772 (average loan about US\$285).

The primary outcome measures used in this project were two indicators of community involvement and 11 health indicators. The hypothesis was that the largest changes in the 11 health indicators would be in the community with the parallel programs, the intermediate changes would be in the community with only the health promotion program, and the smallest changes would be in the community with only the microcredit program. To the authors' knowledge, this is the first published report to attempt to quantify changes in health indicators related to parallel health promotion and microcredit programs as compared to control communities with only a health promotion program or only a microcredit program.

\section{METHODS}

\section{Community descriptions}

The city of San Pedro de Macorís, which is on the southern coast of the Dominican Republic and adjacent to the Caribbean Sea, has a population of about 190 000. Las Filipinas 1 and Las Filipinas 2, which are two adjacent urban neighborhoods in the Barrio Las Filipinas area of the city of San Pedro de Macorís, were the site for the health promotion program. According to a survey conducted by two of the authors (ALD, MND) in May 2001, Barrio Las Filipinas had an average of 4.3 people per household. The monthly household income distribution was: less than RD\$ 1000 : 34.4\%; 1001 to 2 000: 32\%; 2001 to 4 000: 19.1\%; 4001 to 5 000: 6.2\%; and greater than 5 000: $8.3 \%$. At the time of the survey, RD\$ 1000 was equal to about US\$ 60. The local neighborhood council, which provides the local political organization for all of Barrio Las Filipinas, estimated that the population of the entire barrio was about 6000 persons, living in around 1400 households.

Public health, charitable, and private medical clinics are available for curative medicine services in the barrio, which was divided into two neighborhoods (Las Filipinas 1 and Las Filipinas 2), related to the presence or absence of the microcredit program. In our research project, the Las Filipinas 1 neighborhood had only the health promotion program while Las Filipinas 2 had both the health promotion program and the microcredit program.

The semirural community of Ingenio Angelina, located about $6 \mathrm{~km}$ north of San Pedro de Macorís, had only a microcredit program. The population estimate by the local neighborhood council was about 5000 persons, in about 1200 households. Ingenio Angelina has medical clinics from both the public health system and the Social Security system, as well as a few private medical practitioners.

The Dominican national public health system includes clinics and hospitals under the auspices of the Secre- 
tary of State for Public Health and Social Services (SSPHSS) (Secretaría de Estado de Salud Pública y Asistencia Social) and the Dominican Institute for Social Security (DISS) (Instituto Dominicano de Seguridad Social). The SSPHSS public health facilities are open to the general public, and the DISS facilities are restricted to those citizens covered by the Social Security plan. In general all physician services are free at both SSPHSS and DISS facilities, though patients may pay for medicines and supplies used in their care. All childhood vaccines are free of charge. SSPHSS has health promotion activities, with SSPHSS health promoters working out of clinics, often as physician extenders. In comparison, the health promotion program in this study provided community-based (as opposed to clinicbased) health promoters who visited families in their homes on a monthly schedule, and with a much lower ratio of promoters to families than in the SSPHSS system. There were no SSPHSS health promoters working in the study communities during the time of this study.

\section{Microcredit program}

The microcredit program of Esperanza Internacional operates from a field office in the province of San Pedro de Macorís, with most program activity centered in that province and in the surrounding provinces. The Esperanza Internacional microcredit program follows a microenterprise development model, with financial services (credit and savings), training in marketing and accounting, and a community bank in which peer guarantee among borrowers is accepted as collateral (1). Community banks are generally composed of 10 to 20 people who are the recipients of the microloans to be used to start or expand their small business ventures (microenterprises). Microloan recipients may pursue a wide range of business opportunities such as food preparation, vegetable/ fruit sales, baking, used clothing sales, tailoring, laundry services, piece work for larger manufacturing companies, handicrafts, and sandal making. Prospective microloan recipients must complete a course that lasts up to eight months and that covers basic economic principles, accounting techniques, and small business management. Esperanza Internacional made more than 2500 microloans as part of its program in 2002. Average microloans throughout the entire Esperanza Internacional program in the San Pedro de Macorís province and surrounding areas are about US\$240, with repayment usually due at the end of six months. Commercial interest rates are charged on the microloans in order to replicate the actual loan market. In that way the microloan recipients will become accustomed to the conditions of the commercial loan market in case they eventually have sufficient collateral to qualify for a commercial loan for their ongoing business needs. The loan default rate for all Esperanza Internacional microcredit programs is about $2 \%$.

The microcredit programs in Las Filipinas 2 and Ingenio Angelina were part of the larger Esperanza Internacional program and had been operational for at least a year prior to the beginning of the health promotion program.

\section{Health promotion program}

A single health promotion program served Barrio Las Filipinas (including both Las Filipinas 1 and Las Filipinas 2). Volunteer health promoters formed the foundation of the health promotion program under the auspices of the Hope and Charity Clinic (Clínica Esperanza y Caridad), which is a health ministry of the Dominican Episcopal Church (Iglesia Episcopal Dominicana). The Dominican Episcopal Church includes the entire Dominican Republic and is a diocese within The Episcopal Church (part of the worldwide Anglican Communion). The Hope and Charity Clinic is a curative medicine facility, offering services in general medicine, subspecialty medicine (cardiology, pediat- rics, obstetrics/gynecology, gastroenterology, neurology, ophthalmology/ optometry, orthopedics, physiatry, and psychiatry/psychology), rehabilitation services (including physical therapy, speech therapy, and prostheses), and dentistry. Ancillary services include a pharmacy and clinical laboratory.

Criteria to be a volunteer health promoter included the ability to read and write, attendance at the training workshops, attendance at monthly meetings, monthly visitations to their assigned families, and a desire to help one's neighbors and community. Promoters would see each of their assigned families once a month for a visit of at least 15 minutes in order to assess each family's current health situation, to teach on relevant health topics, and to offer whatever other help they could provide.

Volunteer health promoters attended four workshops: the nature of health promotion, and diarrheal diseases and dehydration (20-21 April 2001); breast and cervical cancer screening (7 July 2001); acute respiratory infections (6 October 2001), with a practical on the physical assessment of a child with acute respiratory infection; and immunizations (12 January 2002), with a practical on administering vaccines by injection. (The practical sessions occurred two to three weeks after their respective workshops.) Health promoter materials were adapted from the World Health Organization's Integrated Management of Childhood Illness initiative (5, 6) and local public health materials. Supplies provided to the health promoters included a photo identification badge, an oral thermometer, a 120-mL bottle of chlorine solution and dropper to be used for demonstrating a method for home purification of water, packets of oral rehydration fluid, a breast selfexamination model (a bra stuffed with cotton with a small rock on one side to simulate a mass), a notebook and preprinted pages for recording visits, a ballpoint pen, the workshop manuals configured to be used by the promoters as teaching tools, and a tote bag.

The association with the Hope and Charity Clinic allowed the health pro- 
moters to distribute coupons redeemable for a free Papanicolaou test (Pap test) at that clinic. Two of the authors (ALD, MND) made monthly supervisory visits with each promoter to discuss problems, to encourage the promoter, and to review the written notes of their visits.

The promoters began registering their families and making monthly visits after the first workshop. Initial estimates were that each promoter might have 20 families assigned.

The Barrio Las Filipinas neighborhood council agreed to support the health promotion program after reviewing the results of the initial community survey (see the next subsection) for their barrio, with the council president (a nurse) serving as the liaison. The community council solicited and approved volunteers to be health promoters, assigned work areas to the promoters, and assisted with communication functions such as reminders about the monthly meetings or other events, general monitoring as to whether promoters were making visits to their families, and problem-solving activities such as making adjustments when the initial work assignments were poorly balanced among the promoters.

The health promoters were unaware of the specific health indicators that were to be compared among the three communities. The health promotion program was organized for all of Barrio Las Filipinas, so that a single health promotion program covered both Las Filipinas 1 and Las Filipinas 2. The authors managing the health promotion program (ALD, AC, MND) did not know where the division between Las Filipinas 1 and Las Filipinas 2 was. Thus, the three authors managing the health promotion program were masked as to which sections of Barrio Las Filipinas constituted Las Filipinas 1 and Las Filipinas 2.

\section{Outcome measures and community surveys}

The primary outcome measures included two indicators of community involvement as well as 11 health indi- cators. The two indicators of community involvement were evaluated at the end of the project: (1) at least two community organizations involved in support of the health promotion program in Barrio Las Filipinas and (2) at least 18 volunteer health promoters trained and still working in Barrio Las Filipinas at the time of the follow-up survey. The other 11 items were health indicators evaluated by the use of community surveys. The health indicators were assessed several months before the first health promoter workshop and then after the health promotion program had been in operation for 13 months.

A team trained by two of the coauthors (AC and LS) conducted the community surveys. The persons conducting the surveys were not familiar with the goals or operational specifics of the health promotion program. Interviewers administered the questionnaire using a system in which they started with a random house and then attempted to complete an interview at every fifth house until a total of 27 interviews were finished. This methodology for choosing households for the interviews meant that a different group of households would be interviewed in the initial survey and the follow-up survey. In addition, households would be included in the sample regardless of whether they were involved directly in the microcredit or health promotion programs. The survey instrument contained previously validated items from the Dominican public health service's National Health Questionnaire (Encuesta Nacional de Salud). In the survey results, child or children refers to children 5 years of age or less; woman or women refers to postmenarche females. Any adult male or female head of household could serve as the survey respondent for their household.

Of the 11 health indicators, 3 were related to health knowledge: (1) the importance of using purified water for drinking and food preparation, (2) use of oral rehydration fluid in children with diarrhea, and (3) recognition of signs of serious illness in a child. Using purified water was a concern because no potable water sources were available to residents of Barrio Las Filipinas or Ingenio Angelina other than buying commercially purified bottled water. Sources of nonpotable water included local access points to piped water from extensions of the municipal water system. At these access points, residents could retrieve water from an open reservoir to carry to their homes. Trucks and horse carts also could deliver nonpotable water to individual households.

Six of the 11 indicators were behavioral: (1) households using potable water, (2) households that practice hand-washing before preparing foods, (3) children having completed their basic immunization scheme, (4) women who have had a Pap test in the past year, (5) women who practice breast self-examination monthly, and (6) households that use a sanitary method of garbage disposal, as opposed to simply tossing refuse outside the home or into an empty lot. The final two health indicators were illness rates among the children under 5 years of age who had been selected by the survey respondents in each household as the reference child for: (1) the prevalence rate of diarrhea for the month prior to the questionnaire and (2) the prevalence rate of acute respiratory infections for the month prior to the questionnaire.

The three health knowledge items were open-ended inquiries to which interviewees could give up to three responses. For example, a respondent might be asked, "How would you know that a child is seriously ill?" After the first response, the interviewer could prompt for further information by asking the phrase "And anything else?" once or twice. The responses were compared to preset criteria to determine if the interviewee had included key ideas that indicated understanding of the concept. The interviewers confirmed the answers to most of the behavioral items. For instance, completion of the basic vaccination scheme was verified by checking a completed vaccination record for the child, and the use of potable water was confirmed by at least checking that the family had commercially puri- 
fied water or could demonstrate their method of home purification and sanitary storage of water.

When a household had more than one woman or more than one child, the respondent was asked to identify one woman or one child to be the subject when answering all questions that related to a specific woman's or child's health. When a household had no children or no women, the related health indicator questions were omitted; these omissions (as well as nonresponses from some households) were anticipated to cause variations in the denominators. In other words, some health indicators would have responses from all 27 households, but other indicators would have responses from fewer than 27 households. There might be fewer than 27 responses for two reasons: (1) some households did not have the population of interest for some survey items (that is, households to which the health indicators about women and children did not apply) and (2) households that chose not to respond to a particular survey item. Consequently, the proportions giving the results from the survey for each health indicator were constructed with a numerator equal to the number of households that had the particular indicator and a denominator composed of those households to which the survey item applied and that also answered the question.

The questionnaires included items beyond the 11 primary health indicators of the project, such as additional questions concerning water purification, prevention and management of diarrhea and respiratory illness in children, and participation in microcredit activities.

The initial, baseline community survey occurred over the five days of 29 December 2000 through 2 January 2001. The final community surveys occurred over the seven days of 25 June through 2 July 2002, by which time the health promotion program had been running for about 13 months and about 6 months had passed since the final workshop.

This project involved minimal risk, utilized information collected as part of the planning and evaluation phases of the microcredit and health promotion programs, did not collect and store specific information on identifiable participants, did not have a randomized treatment component, and did not have the characteristics of a clinical trial (7). The investigators conformed to the principles of the Declaration of Helsinki and its amendments from the World Medical Association. The project was not submitted to an independent institutional review board.

\section{Statistics}

The statistics presented in this piece are descriptive and comparative. The statistical significance of the differences between the initial and final proportions for each of the health indicators in each community was assessed using equations for "method II" or purposive sampling (8). Linear regression was used for correlations between variables (9). For the main hypothesis (that the greatest changes would occur in response to the parallel programs, the intermediate changes would be with the health promotion program only, and the smallest changes would happen with the microcredit program alone), the differences between the values for the initial and final proportions for each health indicator for each community (assuming that the underlying distributions could be far from normal) were analyzed using the nonparametric Kruskal-Wallis test (9). As an additional poststudy analysis, logistic regression was used to calculate odds ratios by using the final combined results from all the communities for each health indicator for the presence of the microcredit or health promotion components (9). The Statistix 7 statistics program (Analytical Software, Tallahassee, Florida, United States) was used for calculating linear regression, odds ratios by logistic regression, and the Kruskal-Wallis test, as well as for obtaining specific $P$ values from the normal distribution for test statistics. All tests were two-tailed, and $P$ values less than 0.05 were considered to be significant. The confi- dence intervals (CIs) that are reported are $95 \%$ confidence intervals $(8,10)$.

The formula for determining the "added benefit" of the two parallel programs compared to the effect from the health promotion program alone (and expressing that "added benefit" of the parallel programs as a percentage of the change in the health indicators produced by the health promotion program alone) was:

$$
\frac{(D p-D h)}{D h} \times 100
$$

In that formula, $D p$ was the difference between the final and initial proportions for an individual indicator in the community with the two (parallel) programs, and $D h$ was the difference between the final and initial proportions for an individual indicator in the community that had only the health promotion program.

\section{RESULTS}

The community involvement goals of the health promotion program were achieved in Barrio Las Filipinas, with more than 18 volunteers continuing to work as health promoters and with three community organizations (the Las Filipinas neighborhood council, the Hope and Charity Clinic, and the local Roman Catholic chapel ( $\mathrm{LaCa}$ pilla de Nuestra Señora de Las Mercedes)) supporting the program.

Twenty-five promoters attended the workshop on prevention and management of diarrheal diseases (with 7 additional people later completing a "makeup" workshop), 34 attended the breast and cervical cancer screening workshop, 28 attended the acute respiratory infection workshop, and 33 attended the immunizations workshop. In addition, more than $65 \%$ of the promoters attended the practical sessions on the physical assessment of a child with an acute respiratory infection and on giving vaccines by injection. Promoters ranged in age from adolescents to around 40 years of age, and they were all women except for one adolescent male. Each health promoter had 
TABLE 1. Initial and final proportions for health indicators for each of the three communities studied, Dominican Republic, 2001 to $2002^{a}$

\begin{tabular}{|c|c|c|c|c|c|c|c|c|c|}
\hline \multirow[b]{2}{*}{ Health Indicator } & \multicolumn{3}{|c|}{$\begin{array}{l}\text { Ingenio Angelina } \\
\text { (microcredit program only) }\end{array}$} & \multicolumn{3}{|c|}{$\begin{array}{c}\text { Las Filipinas } 1 \\
\text { (health promotion program only) }\end{array}$} & \multicolumn{3}{|c|}{$\begin{array}{c}\text { Las Filipinas } 2 \\
\text { (microcredit and health pr. programs) }\end{array}$} \\
\hline & Initial & Final & Difference $(\mathrm{Cl})^{\mathrm{b}}$ & Initial & Final & Difference $(\mathrm{Cl})$ & Initial & Final & Difference $(\mathrm{Cl})$ \\
\hline \multicolumn{10}{|l|}{ Understands importance of water } \\
\hline purification & $3 / 27$ & $8 / 26$ & $0.20(-.05, .45)$ & $3 / 26$ & $11 / 26$ & $0.31(.04, .57)^{c}$ & $4 / 27$ & $17 / 27$ & $0.48(.22, .74)^{\mathrm{d}}$ \\
\hline Understands use of oral rehydration & & & & & & & & & \\
\hline solution in diarrhea management & $3 / 27$ & $7 / 25$ & $0.17(-.08, .42)$ & $4 / 27$ & $11 / 27$ & $0.26(-.01, .52)$ & $4 / 24$ & $21 / 26$ & $0.64(.39, .89)^{d}$ \\
\hline \multicolumn{10}{|l|}{ Recognizes signs of serious illness } \\
\hline in a child & $3 / 26$ & $8 / 26$ & $0.19(-.06, .45)$ & $3 / 26$ & $13 / 27$ & $0.37(.10, .63)^{\mathrm{c}}$ & $4 / 27$ & $20 / 22$ & $0.76(.54, .98)^{\mathrm{d}}$ \\
\hline Households using potable water & $6 / 27$ & $12 / 26$ & $0.24(-.05, .52)$ & $8 / 25$ & $16 / 26$ & $0.30(-.01, .60)$ & $15 / 26$ & $22 / 24$ & $0.34(.08, .60)^{c}$ \\
\hline $\begin{array}{l}\text { Hand-washing before food preparation } \\
\text { Households using sanitary garbage }\end{array}$ & $3 / 27$ & $8 / 27$ & $0.19(-.06, .43)$ & $4 / 25$ & $11 / 26$ & $0.26(-.01, .54)$ & $5 / 25$ & $22 / 27$ & $0.61(.36, .87)^{\mathrm{d}}$ \\
\hline disposal & $4 / 27$ & $5 / 24$ & $0.06(-.19, .31)$ & $4 / 24$ & $7 / 27$ & $0.09(-.17, .35)$ & $6 / 27$ & $11 / 26$ & $0.20(-.08, .48)$ \\
\hline \multicolumn{10}{|l|}{ Children 5 yr old and under having } \\
\hline completed the basic vaccination scheme & $4 / 27$ & $7 / 26$ & $0.12(-.13, .38)$ & $4 / 24$ & $14 / 26$ & $0.37(.09, .65)^{\mathrm{c}}$ & $5 / 27$ & $20 / 22$ & $0.72(.49, .95)^{\mathrm{d}}$ \\
\hline Women who had a Pap test within & & & & & & & & & \\
\hline the past year & $3 / 26$ & $7 / 26$ & $0.15(-.09, .40)$ & $8 / 26$ & $20 / 27$ & $0.43(.15, .71)^{\mathrm{e}}$ & $10 / 27$ & $22 / 24$ & $0.55(.29, .80)^{d}$ \\
\hline \multicolumn{10}{|l|}{ Women who practice monthly breast } \\
\hline self-examination & $3 / 27$ & $5 / 27$ & $0.07(-.15, .30)$ & $4 / 27$ & $7 / 27$ & $0.11(-.14, .36)$ & $4 / 25$ & $10 / 24$ & $0.26(-.03, .54)$ \\
\hline Children with diarrhea in the past 30 days & $19 / 26$ & $17 / 26$ & $-0.08(-.37, .21)$ & $17 / 26$ & $9 / 25$ & $-0.29(-.60, .01)$ & $15 / 27$ & $3 / 24$ & $-0.43(-.70,-.16)^{\mathrm{e}}$ \\
\hline Children with acute respiratory infection & & & & & & & & & \\
\hline in the past 30 days & $18 / 26$ & $11 / 24$ & $-0.23(-.54, .07)$ & $15 / 26$ & $6 / 26$ & $-0.35(-.63,-.06)^{c}$ & $11 / 26$ & $4 / 24$ & $-0.26(-.54, .03)$ \\
\hline
\end{tabular}

from 7 to 29 families (median of 16 families), 22 promoters worked on a continuing basis, and over 400 families in the community had an active health promoter.

Besides the topics covered in the workshops, the promoters also intervened in other situations they discovered while visiting homes. Examples included arranging evaluation for a man with incapacitating schizophrenia and assisting pregnant women to receive prenatal care.

Twenty-seven surveys were completed in each of the three communities during the initial survey period and also during the final survey period. Results for the health indicators improved in all the communities (Table 1), though the degree of change was different among the communities $(P<0.001)$. The columns labeled "Initial" and "Final" for each community in Table 1 are the actual proportions for each health indicator from the initial and final surveys. The numerator in each proportion is the number of positive responses to that survey item, and the denominator is the number of respondents.

Las Filipinas 2, the community with parallel microcredit and health promotion programs, had the largest changes for 10 of the 11 indicators. Las Filipinas 1, the community with only the health promotion program, had the largest change for one health indicator (30-day prevalence of acute respiratory infection), and the intermediate changes for all the other indicators. Ingenio Angelina, the community with only the microcredit program, had the smallest changes for each of the indicators. The community with parallel programs had 8 indicators change significantly. The community with only the health promotion program had 5 indicators change significantly. The community with just the microcredit program had no indicators change significantly. Households using sanitary garbage disposal (which was not a focus of the health promotion program) did not change significantly in any community.

Odds ratios for the microcredit and health promotion components for each health indicator were calculated from the combined final results of all three communities (Table 2). These odds ratios represent the odds favoring the presence of the health indicator when the component (either the health promotion or the microcredit component) is present compared to when that component is absent. The odds ratios are not precise (as indicated by the large 95\% CIs), but they indicate that there was probably an effect (that is, the 95\% CI does not include 1.0) from the health promotion program on 9 of the 11 health indicators and from the microcredit program on 5 of the 11 indicators. For each of the health indicators, the odds ratio indicates a more substantial impact from the health promotion program than from the microcredit program. 
TABLE 2. Odds ratio (OR) with $95 \%$ confidence interval $(\mathrm{Cl})$ for the health and microcredit components for each health indicator from the combined final survey results from all three communities, Dominican Republic, 2002

\begin{tabular}{|c|c|c|c|c|}
\hline \multirow[b]{2}{*}{ Health Indicator } & \multicolumn{2}{|c|}{ Health component } & \multicolumn{2}{|c|}{ Microcredit component } \\
\hline & OR & $(95 \% \mathrm{Cl})$ & OR & $(95 \% \mathrm{Cl})$ \\
\hline $\begin{array}{l}\text { Understands importance of water } \\
\text { purification }\end{array}$ & 3.8 & $(1.2,11)$ & 2.3 & $(0.77,7.0)^{a}$ \\
\hline $\begin{array}{l}\text { Understands use of oral rehydration } \\
\text { solution in diarrhea management }\end{array}$ & 11 & $(2.9,40)$ & 6.1 & $(1.8,21)$ \\
\hline $\begin{array}{l}\text { Recognizes signs of serious illness } \\
\text { in a child }\end{array}$ & 22 & $(4.2,120)$ & 11 & $(2.1,55)$ \\
\hline Households using potable water & 13 & $(2.5,64)$ & 6.9 & $(1.4,35)$ \\
\hline Hand-washing before food preparation & 13 & $(3.4,36)$ & 6.0 & $(1.7,21)$ \\
\hline $\begin{array}{l}\text { Households using sanitary garbage } \\
\text { disposal }\end{array}$ & 2.6 & $(0.75,9.1)^{\mathrm{a}}$ & 2.0 & $(0.62,6.2)^{a}$ \\
\hline $\begin{array}{l}\text { Children } 5 \mathrm{yr} \text { and under having } \\
\text { completed the basic vaccination scheme }\end{array}$ & 27 & $(5.1,145)$ & 8.6 & $(1.7,44)$ \\
\hline $\begin{array}{l}\text { Women who had a Pap test within } \\
\text { the past year }\end{array}$ & 25 & $(4.8,128)$ & 3.9 & $(0.73,20)^{\mathrm{a}}$ \\
\hline $\begin{array}{l}\text { Women who practice monthly breast } \\
\text { self-examination }\end{array}$ & 3.1 & $(0.89,11)^{\mathrm{a}}$ & 2.0 & $(0.63,67)^{\mathrm{a}}$ \\
\hline Children with diarrhea in the past 30 days & 0.08 & $(0.02,0.32)$ & 0.27 & $(0.06,1.2)^{\mathrm{a}}$ \\
\hline $\begin{array}{l}\text { Children with acute respiratory infection } \\
\text { in the past } 30 \text { days }\end{array}$ & 0.24 & $(0.06,0.90)$ & 0.67 & $(0.16,2.7)^{\mathrm{a}}$ \\
\hline
\end{tabular}

There was a strong negative relationship in our results between the prevalence of diarrhea and the use of potable water at each survey time in each community $(P=0.0038)$.

The added benefit of the parallel programs (expressed as a percentage of the change produced by the health promotion program alone) was variable. Percent differences for the 11 individual indicators ranged from the single negative value of $-26.0 \%$ to the positive value of $147 \%$, with a mean of $77.2 \%$ (standard deviation of 56.8\%) and median of $94.7 \%$. In other words, the results were generally about $75 \%$ better with the parallel programs than with the health promotion program alone, though the effect varied greatly.

\section{DISCUSSION}

Microcredit is increasingly viewed as an effective and sustainable method to address poverty worldwide (11). Multiple relationships exist between economic status and health status on both the macroeconomic and micro- economic levels $(1,12,13)$. The results of this project support the view that multisector development, known to be important on a macroeconomic scale $(12,13)$, is also important on a microeconomic level. For 10 of the 11 health indicators, the improvement was greatest in Las Filipinas 2, the community with the parallel health promotion and microcredit programs, and this occurred despite the fact that the health indicators were generally better in Las Filipinas 2 on the initial survey compared to the other two communities.

The community with only the microcredit program to impact the health indicators is an example of the minimalist model of microeconomic development to improve health status. There were no significant changes in health indicators in that community. However, the microcredit program preexisted the project period, and it is unknown whether the initiation of that program may have been associated with general health improvements. The model of integrated microeconomic development and health programs (which was not addressed in this project that dealt with parallel programs) is known to increase health knowledge, change behaviors, and improve children's nutritional status (14).

The setting of this health promotion program was in an urban environment. Presently, $75 \%$ of the population of the Americas lives in urban areas, and that percentage is increasing (12, 13). Microcredit and health promotion programs must be able to produce results in urban areas, where the poor may be concentrated both within and around the cities.

Conceivably, participants in microcredit programs are a self-selected subgroup who are more proactive in managing their lives. Such a subgroup might be expected to benefit more fully from development programs. For this reason, the survey methods were designed to sample from the entire community and not only from the families with microloans.

An economic aphorism states that the overall economy reflects not how much money there is, but rather how it moves. Thus, microenterprise may enrich a community beyond the direct benefits to microloan recipients, given that economic activity may increase in the neighborhood. Side effects of microenterprise development can be economic or social as women are empowered and new social systems and political alliances emerge (14-16). A similar effect may be posited for a community-based health program. Anecdotal evidence suggests that beneficiaries of the health promoter program extended beyond those families who had an assigned health promoter. Families without an assigned health promoter reported having received health information from neighbors or family members who did have an assigned health promoter. In addition, some promoters used the promotion materials to speak to community groups. While it is impossible to estimate, there was evidently a degree of secondary transmission of the health promoters' messages. As an example, the increase in the rate of women who had a Pap test cannot be accounted for solely by families assigned to health promoters. Promoters distributed about 700 tickets 
for free Pap tests, of which about 400 were redeemed. Other avenues for free or low-cost Pap tests were available through public health clinics and other sources both before and during the time period of this study. However, the distribution of the tickets itself carried an implicit message regarding the importance of this screening test. While we have no specific information concerning any long-term behavioral and social transformations, conceivably the process of the volunteers promoting Pap tests may have encouraged a wider discussion among women in the neighborhood or even begun a paradigm shift toward more consistent Pap test screening.

Some health indicators may have had a more direct economic component. There was a strong negative relationship between the prevalence of diarrhea and the use of potable water, water being a well-established vehicle for transmission of the microorganisms that cause diarrhea $(12,13,17,18)$.

Home water purification by boiling or utilizing chlorine solution was taught by the health promoters. Those two methods can produce water that meets World Health Organization microbiological standards for potable water (19). However, while such home-based water purification methods can decrease the rates of diarrhea and other waterborne diseases (20), they do not produce consistently good results. One study using microbiological assays of drinking water from homes that reported using home water purification methods found that only $16 \%$ of the samples were free of coliforms; even when two home purifica- tion methods were utilized, only $38 \%$ of samples were free of coliforms (21). Home purification methods are unlikely to produce the same degree of safety across a community as provided by commercially purified water.

Commercially purified bottled water is widely available for purchase in the Dominican Republic. There may have been a direct health advantage for families with the financial resources to purchase purified water when compared to families using home purification methods. While the motivation may have been identical, the financial freedom to utilize the more expensive (and probably more effective) option of commercially purified water could have produced the larger decrease in diarrhea prevalence in Las Filipinas 2, where both the health promotion and microcredit programs were operating. If purchase of purified water was a component of the decreased diarrhea prevalence, similar results from parallel microcredit and health promotion programs cannot be expected where commercially purified water is not available. Or, from a larger perspective, the general availability within the community of effective resources for improving health could be an important component in the interaction between parallel health promotion and microcredit programs.

Available community resources may also have had a role in the two areas in which the health promotion program had the highest odds ratios: vaccinations and Pap tests. Both of these indicators are dependent on technical medicine, specifically vaccine production and maintenance of the cold chain for vaccines and facilities for processing and interpreting Pap tests. The availability of vaccines and Pap testing in the community (and perhaps the specific association with the Hope and Charity Clinic, a curative medicine facility) undoubtedly contributed to the improvements that were observed in these indicators.

Poverty is related both to deprivations, such as poor health and illiteracy, that are intrinsically important and to factors, such as low income, that may play a decisive role $(12,13)$. Poor health and illiteracy are the main determinants of the transgenerational transmission of poverty $(12,13)$. Effective approaches to alleviating poverty may need to address these multiple factors. Additional research is needed to better define the role of parallel microeconomic development and health promotion programs and the best methods for their use within a multisector development environment.

Acknowledgments. The authors thank Leopoldina Castro, President of the Barrio Las Filipinas neighborhood council (La Junta de Vecinos Las Mercedes), and Ercilia Santana, Administrator of La Clínica Esperanza y Cari$\mathrm{dad}$, for their support and assistance throughout this project. The authors also thank Donald Smith and the Allnutt Health Sciences Library, St. Elizabeth Medical Center, Edgewood, Kentucky, United States, for providing medical library services. Partial funding for this project was provided by a grant from Summit Alliance Global Health, of Breckenridge, Colorado, United States.

\section{REFERENCES}

1. Rodriguez-Garcia R, Macinko JA, Waters WF, eds. Microenterprise development for better health outcomes. Westport, Connecticut: Greenwood Press; 2001.

2. Smith SC. Microcredit and health programs: to integrate or not to integrate? An economist's perspective. In: RodriguezGarcia R, Macinko JA, Waters WF, eds. Microenterprise development for better health outcomes. Westport, Connecticut: Greenwood Press; 2001. Pp. 41-50.
3. Pan American Health Organization. Volume II: Health in the Americas. 2002 ed. Washington, D.C.: PAHO; 2002. (Scientific and Technical Publication 587).

4. Organización Panamericana de la Salud. Volumen II: La Salud en las Américas. 2002 ed. Washington, D.C.: OPS; 2002. (Publicación Científica y Técnica 587).

5. World Health Organization, Division of Diarrhoeal and Acute Respiratory Disease Control. Integrated management of the sick child. Bull World Health Organ. 1995; 73:735-40.

6. Gove S. Integrated management of childhood illness by outpatient health workers: technical basis and overview. Bull World Health Organ. 1997;75(suppl 1):7-24.

7. National Bioethics Advisory Commission. Ethical and policy issues in international research: clinical trials in developing countries. Bethesda, Maryland: NBAC; 2001. 
8. Fleiss JL. Statistical methods for rates and proportions. 2nd ed. New York: John Wiley \& Sons; 1981.

9. Rosner B. Fundamentals of biostatistics. 3rd ed. Boston: PWS-Kent Publishing Company; 1990.

10. Gardner MJ, Altman DG, eds. Statistics with confidence. London: British Medical Journal; 1989.

11. United States, Agency for International Development. Microcredit - an emerging tool for fighting poverty. USAID Dev 1997;3(2):2.

12. Pan American Health Organization. Volume I: Health in the Americas. 2002 ed. Washington, D.C.: PAHO; 2002. (Scientific and Technical Publication 587).

13. Organización Panamericana de la Salud. Volumen I: La Salud en las Américas. 2002 ed. Washington, D.C.: OPS; 2002. (Publicación Científica y Técnica 587).

14. Dunford C, MkNelly B. Using microfinance to improve health and nutrition security. Global HealthLink. 2002;118:9, 22.
15. Amin R, Becker S, Bayes A. NGOpromoted microcredit programs and women's empowerment in rural Bangladesh: quantitative and qualitative evidence. J Dev Areas. 1998;32:221-36.

16. MkNelly B, McCord M. Women's empowerment. Davis, California: Freedom From Hunger; 2001. Available from: http:// www.ffhtechnical.org/publications / summary/cweimpactrevuloct01.html [Internet site]. Accessed 22 July 2003. (Credit with Education Impact Review No. 1).

17. Keystone JS, Kozarsky PE. Health advice for international travel. In: Guerrant RL, Walker DH, Weller PF, eds. Tropical infectious diseases: principles, pathogens, \& practice. Philadelphia: Churchill Livingston; 1990. Pp. 1345-65.

18. Valdez LM, Gotuzzo E, DuPont HL. Gastrointestinal symptoms. In: Guerrant RL, Walker DH, Weller PF, eds. Tropical infectious diseases: principles, pathogens, \& practice. Philadelphia: Churchill Livingston; 1990. Pp. 1367-79.
19. Quick RE, Venczel LV, Gonzalez O, Mintz ED, Highsmith AK, Espada A, et al. Narrow-mouthed water storage vessels and in situ chlorination in a Bolivian community: a simple method to improve drinking water quality. Am J Trop Med Hyg. 1996;54(5):511-6.

20. Mintz ED, Reiff FM, Tauxe RV. Safe water treatment and storage in the home. A practical new strategy to prevent waterborne disease. JAMA. 1995;273(12):94853.

21. Luby SP, Syed AH, Atiullah N, Faizan MK, Ficher-Hoch S. Limited effectiveness of home drinking water purification efforts in Karachi, Pakistan. Int J Infect Dis. 2000;4(1):3-7.

Manuscript received 27 February 2003. Revised version accepted for publication on 15 August 2003.
RESUMEN

Cambios en los indicadores de salud relacionados con programas de promoción de la salud y de microcréditos en la República Dominicana
Objetivo. Evaluar el impacto de programas de promoción de la salud y de microcréditos en tres comunidades de la República Dominicana. Una comunidad tenía solo un programa de promoción de la salud, otra contaba solo con un programa de microcréditos y una tercera comunidad contaba con ambos programas. Este proyecto piloto evaluó varias hipótesis: que los mayores cambios en los 11 indicadores de salud estudiados se verificarían en la comunidad que contaba tanto con un programa de promoción de la salud como con un programa de microcréditos; que habría cambios intermedios en la comunidad que solo tenía el programa de promoción de la salud, y que los menores cambios tendrían lugar en la comunidad que contaba solo con el programa de microcréditos.

Métodos. Los programas de promoción de la salud pusieron a voluntarios de la comunidad a hablar con la población acerca de dos grandes problemas: 1) las causas de mortalidad entre niños menores de 5 años de edad y 2) la salud de las mujeres (específicamente, el tamizaje del cáncer de mama y cervicouterino). El programa de microcréditos facilitaba préstamos personales pequeños para establecer o ampliar pequeñas empresas.

Se compararon los valores de 11 indicadores de salud registrados durante las encuestas iniciales (27 viviendas encuestadas en cada una de las tres comunidades) realizadas entre diciembre de 2000 y enero de 2001 y las encuestas de seguimiento (27 viviendas encuestadas en cada una de las tres comunidades) realizadas entre junio y julio de 2002, después de que el programa de promoción de la salud había estado en marcha por alrededor de 13 meses. Tanto en las encuestas iniciales como en las de seguimiento, las viviendas se seleccionaron de forma aleatoria, independientemente de su relación con los programas de microcréditos o de promoción de la salud.

Resultados. Los indicadores de salud mejoraron en las tres comunidades, pero la magnitud de los cambios fue diferente en cada una $(P<0,001)$. La comunidad con programas paralelos de microcréditos y de promoción de la salud presentó los mayores cambios en 10 de los 11 indicadores de salud evaluados.

Conclusiones. Se sabe que el desarrollo multisectorial es importante a escala macroeconómica. Los resultados de este proyecto piloto avalan el criterio de que el desarrollo multisectorial es también importante a escala microeconómica, ya que los programas paralelos de microcréditos y de promoción de la salud produjeron mayores cambios en los indicadores de salud evaluados que cualquiera de esos dos programas individualmente. Hasta donde conocen los autores, este es el primer estudio publicado en que se cuantifican los cambios en los indicadores de salud relacionados con programas paralelos de promoción de la salud y de microcréditos y en que dichos cambios se comparan con los observados en comunidades de control que solo contaban con un programa de promoción de la salud o con un programa microcrediticio, pero no ambos. 